\title{
Avicequinone $B$ sensitizes anoikis in human lung cancer cells
}

\author{
Arisara Prateep ${ }^{1 \dagger}$, Somruethai Sumkhemthong ${ }^{1 \dagger}$, Wiranpat Karnsomwan ${ }^{2}$, Wanchai De-Eknamkul ${ }^{2}$, \\ Supakarn Chamni ${ }^{2}$, Pithi Chanvorachote ${ }^{3,4^{*}}$ and Chatchai Chaotham ${ }^{1,4^{*}}$
}

\begin{abstract}
Background: During metastasis, cancer cells require anokis resistant mechanism to survive until reach the distant secondary tissues. As anoikis sensitization may benefit for cancer therapy, this study demonstrated the potential of avicequinone $B$, a natural furanonaphthoquinone found in mangrove tree (Avicenniaceae) to sensitize anoikis in human lung cancer cells.

Methods: Anoikis inducing effect was investigated in human lung cancer H460, H292 and H23 cells that were cultured in ultra-low attachment plate with non-cytotoxic concentrations of avicequinone B. Viability of detached cells was evaluated by XTT assay at 0-24 h of incubation time. Soft agar assay was performed to investigate the inhibitory effect of avicequinone $B$ on anchorage-independent growth. The alteration of anoikis regulating molecules including survival and apoptosis proteins were elucidated by western blot analysis.
\end{abstract}

Results: Avicequinone B at $4 \mu \mathrm{M}$ significantly induced anoikis and inhibited proliferation under detachment condition in various human lung cancer cells. The reduction of anti-apoptotic proteins including anti-apoptotic protein B-cell lymphoma 2 (BCl-2) and myeloid cell leukemia 1 (Mcl-1) associating with the diminution of integrin/focal adhesion kinase (FAK)/Proto-oncogene tyrosine-protein kinase ( $\mathrm{Src}$ ) signals were detected in avicequinone B-treated cells.

Conclusions: Avicequinone B sensitized anoikis in human lung cancer cells through down-regulation of anti-apoptosis proteins and integrin-mediated survival signaling.

Keywords: Lung cancer, Anoikis, Survival pathway, Avicequinone B, Furanonaphthoquinone

\section{Background}

Lung cancer is a high prevalence and leading cause of death in cancer patients worldwide [1]. Metastasis or the spreading of cancer cells from primary site to secondary vital organs is a major cause of mortality in the lung cancer $[2,3]$. According to highly metastatic features, most of lung cancer patients are frequently diagnosed at advanced stage presenting dissemination of tumor pathology $[4,5]$. Such concepts lead to the urgent need for anti-metastasis therapy for lung cancer.

In the process of metastasis, most population of detached cancer cells should die by the mechanism of detachment-

\footnotetext{
* Correspondence: pithi_chan@yahoo.com; cchoatham@gmail.com

${ }^{\dagger}$ Equal contributors

${ }^{3}$ Department of Pharmacology and Physiology, Faculty of Pharmaceutical

Sciences, Chulalongkorn University, Bangkok 10330, Thailand

${ }^{1}$ Department of Biochemistry and Microbiology, Faculty of Pharmaceutical

Sciences, Chulalongkorn University, Bangkok 10330, Thailand

Full list of author information is available at the end of the article
}

induced apoptosis termed "anoikis" [6]. This specific pattern of cell death is caused by the reduction of cellular survival signals providing by the adhesion of the cells to appropriate surface or membrane through integrins [7]. Loss of the interaction between integrins, cellular adhesive molecules and extracellular matrix (ECM) leads to the deprivation of survival signals following with apoptosis cell death in non-adherent cells [8].

Anoikis is believed to be a critical mechanism in preventing non-adherent cell growth and the growth of cells in an inappropriate environment [9]. In order to survive in blood or lymphatic circulation, certain cancer cells acquire anoikis resistance mechanisms. In metastatic cells, anoikis is inhibited by the increase of survival signals through the modulation of integrins expression contributing activation of FAK (focal adhesion kinase)/Src (proto-oncogene tyrosineprotein kinase) and PI3K (phosphatidylinositol-4,5-bisphosphate 3-kinase)/AKT (phospho kinase B) pathway [10-14]. 
Caveolin-1 was previously shown to play a role in attenuating anoikis response in lung cancer cells by maintain the level of Mcl-1 [15-17]. Moreover, the up-regulation of antiapoptosis Bcl-2 family proteins including Bcl-2 (B-cell lymphoma 2) and Mcl-1 (myeloid cell leukemia 1) has been associated with anoikis resistance and highly metastasis cancer cells [18-20].

Avicequinone B, naphtho [2, 3-b] furan-4, 9-dione isolated from mangrove tree such as Avicennia alba and Avicennia marina has been shown to possess several pharmacological activities [21]. Anticancer activity of naphthoquinone derivatives have been illustrated through the induction of apoptosis and the inhibition on migration and invasion $[22,23]$. So far, the potentials of these furanonaphthoquinone compounds for sensitizing anoikis and their regulatory approaches are largely unknown. We aimed to investigate the anoikis sensitizing effect and the underlying mechanisms of action of avicequinone B in human lung cancer cells. The information obtained from this study will emphasize the therapeutic benefits of avicequinone B for further development as an effective anticancer drug.

\section{Method}

\section{Chemical reagents}

All chemical reagents used for synthesis of avicequinone $B$ and cell culture including XTT (2,3-b-(2-methoxy-4-nitro5-sulfophenyl)-2H-tetrazolium-5-carboxanilide salt), MTT (3-(4,5-Dimethylthiazol-2-yl)-2,5-diphenyltetrazolium bromide), Hoechst33342, propidium iodide (PI), DMSO (dimethysulfoxide) and agarose were purchased from Sigma Chemical, Inc. (St. Louis, MO, USA). Annexin V-FITC for apoptosis detection was provided by Thermo Fisher Scientific (Waltham, MA, USA). Primary antibody of Bcl-2, Mcl1 , Bax (Bcl-2-associated X protein), caveolin-1, integrin $\beta 1$, integrin $\beta 3$, FAK, p-FAK (Try 397), Src, p-Src (Try 418), AKT, p-AKT (Ser 473), ERK (extracellular signal-regulated kinase), p-ERK (Thr 981), $\beta$-actin and specific horseradish peroxidase (HRP)-link secondary antibody were obtained from Cell Signaling Technology, Inc. (Danver, MA, USA). Supersignal West Pico, a chemiluminescence substrate for western blot analysis was purchased from Thermo Fisher Scientific (Waltham, MA, USA). Protease inhibitor cocktail and Bicinchoninic acid (BCA) protein assay kit were obtained from Roche Applied Science (Indianapolis, IN, USA) and Pierce Biotechnology (Rockford, IL, USA), respectively.

\section{Preparation of avicequinone B}

Avicequinone B was prepared from chemical synthesis using a facile synthesis as previous report [24]. Briefly, anhydrous solvents were dried over $4 \AA$ A molecular sieves. Methyl vinyl sulfone (4.71 mmol, $500 \mathrm{mg}$ ) was dissolved in dry dichloromethane $\left(\mathrm{CH}_{2} \mathrm{Cl}_{2}, 10 \mathrm{ml}\right)$ in a $50-\mathrm{mL}$ oven-dried round-bottomed flask. The reaction mixture was stirred at room temperature under an argon atmosphere. Next, neat bromine $\left(\mathrm{Br}_{2}, 7.07 \mathrm{mmol}, 0.2 \mathrm{ml}\right)$ was slowly added into the reaction. Then, the reaction mixture was refluxed for $6 \mathrm{~h}$, concentrated under reduce pressure and reconstituted in dry tetrahydrofuran (THF, $20 \mathrm{ml}$ ). The reaction solution was then cooled at $0{ }^{\circ} \mathrm{C}$ and 1,8-diazabicyclo[5.4.0] undec-7ene (DBU, $7.07 \mathrm{mmol}, 1.1 \mathrm{ml}$ ) was slowly added dropwise over $20 \mathrm{~min}$. The reaction mixture was stirred at $0{ }^{\circ} \mathrm{C}$ for $30 \mathrm{~min}$. Next, lawsone (4.71 mmol, $820.2 \mathrm{mg}$ ) was added and another portion of DBU $(7.07 \mathrm{mmol}, 1.1 \mathrm{ml})$ was slowly added dropwise over $20 \mathrm{~min}$. The reaction mixture was stirred at $0{ }^{\circ} \mathrm{C}$ for $30 \mathrm{~min}$. The reaction was warmed up to room temperature and heated to reflux for $6 \mathrm{~h}$. The reaction was then concentrated under reduced pressure and the residue was dissolved in dichloromethane $(100 \mathrm{ml})$, washed with water $(100 \mathrm{ml})$ and saturated aqueous ammonium chloride $(100 \mathrm{ml})$. The organic layer was separated and the aqueous layer was extracted with dichloromethane (50 $\mathrm{ml} \times 3$ times). The combined organic layer was dried over anhydrous sodium sulfate and concentrated to obtain the crude product. The crude product was purified over silica gel column chromatography using dichloromethane: hexanes $(3: 1 v / v)$ as eluent to provide avicequinone $\mathrm{B}$ as a pale yellow solid at a yield of $69 \mathrm{mg}(12 \%) .{ }^{1} \mathrm{H}-\mathrm{NMR}$ $\left(\mathrm{CDCl}_{3}, 300 \mathrm{MHz}\right) \delta 8.22(1 \mathrm{H}, \mathrm{m}, 5-\mathrm{H}), 8.22(1 \mathrm{H}, \mathrm{m}, 8-\mathrm{H})$, $7.77(1 \mathrm{H}, \mathrm{m}, 6-\mathrm{H}), 7.77(1 \mathrm{H}, \mathrm{m}, 7-\mathrm{H}), 7.77(1 \mathrm{H}, \mathrm{d}, \mathrm{J}=1$. $5 \mathrm{~Hz}, 2-\mathrm{H}), 7.01(1 \mathrm{H}, \mathrm{d}, \mathrm{J}=1.5 \mathrm{~Hz} 3-\mathrm{H}) ;{ }^{13} \mathrm{C}-\mathrm{NMR}\left(\mathrm{CDCl}_{3}\right.$, $300 \mathrm{MHz}) \delta 180.6$ (C-4), 173.6 (C-9), 152.7 (C-9a), 148.6 (C-2), 132.5 (C-4a), 134.0 (C-7), 133.9 (C-6), 133.2 (C-8a), 130.5 (C-3a), 127.1 (C-8), 127.0 (C-5), 108.7 (C-3); IR (KBr) 3142, 2853, 1683, 1585, 1566, 1478, 1365, 1206, 1182, 952, $714 \mathrm{~cm}^{-1}$; HRMS-ESI m/z $221.0212\left([\mathrm{M}+\mathrm{Na}]^{+}\right.$, calcd for $\mathrm{C}_{12} \mathrm{H}_{6} \mathrm{O}_{3} \mathrm{Na}^{+}$221.0215). Spectroscopic data of avicequinone $\mathrm{B}$ were matched with the previous report. The synthetic scheme of avicequinone B was demonstrated in Fig. 1.

\section{Cell culture}

Human lung cancer H460, H292 and H23 cells were obtained from ATCC, American Type Culture Collection (Manassas, VA, USA). They were maintained in RPMI (Roswell Park Memorial Institute) medium supplemented with 10\% fetal bovine serum (FBS), $2 \mathrm{mmol} / \mathrm{l} \mathrm{L}$-glutamine and 100 units/ml penicillin/streptomycin (Gibco, Gaithersburg, MA, USA) under $5 \% \mathrm{CO}_{2}$ at $37{ }^{\circ} \mathrm{C}$. The cells that reached $70-80 \%$ confluence were used for next experiments.

\section{Cell viability assay}

Cell viability of adherent cell was evaluated by MTT assay. Briefly, lung cancer cells were cultured in complete RPMI medium containing various concentrations $(0-10 \mu \mathrm{M})$ of avicequinone B for $24 \mathrm{~h}$. The cells were then incubated with $0.4 \mathrm{mg} / \mathrm{ml}$ of MTT solution at $37{ }^{\circ} \mathrm{C}$ in a dark place for $4 \mathrm{~h}$. The MTT solution was 
<smiles>O=C1C=C(O)C(=O)c2ccccc21</smiles>

Lawsone<smiles>C=CS(C)(=O)=O</smiles>

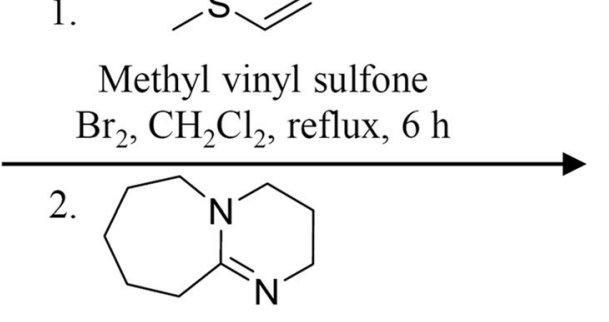

DBU<smiles>O=C1c2ccccc2C(=O)c2occc21</smiles>

Avicequinone B

THF, $0{ }^{\circ} \mathrm{C}, 30 \mathrm{~min}$ then

reflux, $6 \mathrm{~h} ; 12 \%$ (2 steps)

Fig. 1 Synthetic scheme of avicequinone B

replaced with DMSO $(100 \mu \mathrm{l} /$ well $)$ to dissolve the purple formazan crystal. The intensity of formazan color was measured at $570 \mathrm{~nm}$ using a microplate reader (Anthros, Durham, NC, USA). Percentage of cell viability in relation to the non-treated control was calculated from the optical density (OD) ratio of treated to non-treated control cells.

In order to evaluate anti-proliferative activity of avicequinone $\mathrm{B}$, human lung cancer $\mathrm{H} 460$ cells were prepared at density of $2 \times 10^{3}$ cells/well in 96 well-plate. The cells were incubated with non-toxic concentrations of avicequinone B or left untreated for 24, 48 and $72 \mathrm{~h}$ then cell viability was examined via MTT assay. The \%cell proliferation was obtained from the calculation between OD of the cells at each time point divided by OD of nontreated control at $24 \mathrm{~h}$.

\section{Detachment-induced cell death}

A single-cell suspension of human lung cancer cells at a density of $1.5 \times 10^{5}$ cells $/ \mathrm{ml}$ was prepared in RPMI culture medium. In order to prevent anchorage, lung cancer single-cell suspension was culture in an ultra-low attachment plate (Corning, Acton, MA, USA). The cells were treated with non-toxic concentrations of avicequinone B for $0,6,9,12$ and $24 \mathrm{~h}$ or left untreated. After indicated time point, the cells were harvested for evaluation of cell viability through the incubation with $20 \mu \mathrm{M}$ of XTT at $37{ }^{\circ} \mathrm{C}$ for $4 \mathrm{~h}$. The intensity of the formazan product from XTT was measured at $450 \mathrm{~nm}$ using a microplate reader.

\section{Detection of mode of cell death}

Nuclear staining with Hoechst33342 $(10 \mu \mathrm{M})$ and PI (5 $\mu \mathrm{g} / \mathrm{ml}$ ) was performed to detect apoptosis and necrosis cell death in human lung cancer cells treated with avicequinone B. Bright blue fluorescence of Hoechst33342 and red fluorescence of PI were observed and evaluated under fluorescent microscope (Olympus
IX51 with DP70; Olympus, Melville, NY, USA) as apoptosis and necrosis cells, respectively. For evaluation on detachment-induced apoptosis or anoikis, single-cell suspension of human lung cancer cells treated non-toxic concentrations of avicequinone B for $24 \mathrm{~h}$ in ultra-low attachment plate were collected and co-stained with Hoechst33342/PI [25, 26]. Mode of cell death were examined and counted under fluorescent microscope.

The relative ratio of amount of apoptosis cells to total cell number was presented as \%apoptosis and \%anoikis for attachment and detachment culture condition, respectively.

\section{Annexin V/PI flow cytometry analysis}

Anoikis in non-adherent cells was further evaluated through flow cytometry using an Annexin V-FITC apoptosis assay kit. Single-cell suspension of $\mathrm{H} 460$ cells cultured in an ultra-low attachment 6 well-plate at a density of $1.5 \times 10^{5}$ cells $/ \mathrm{ml}$ were collected after incubated with $0-4 \mu \mathrm{M}$ of avicequinone B for $24 \mathrm{~h}$. The cells were washed and resuspended in phosphate buffer saline (PBS), $\mathrm{pH}$ 7.4. The single-cell suspensions were then centrifuged and dispersed in binding buffer $(100 \mu \mathrm{l})$. Annexin V-FITC $(1 \mu \mathrm{g} / \mathrm{ml})$ and PI $(2.5 \mu \mathrm{g} / \mathrm{ml})$ were added into the cell suspensions as recommended in the manufacturer's instructions. Living, apoptosis and necrosis cells were analyzed via a FACScan flow cytometer using CellQuest software (Becton-Dickinson, Redlands, CA, USA).

\section{Anchorage-independent growth assay}

The ability to proliferate under detachment condition of human lung cancer cells was investigated in soft agar assay. Each well of a 24 well-plate was covered with $500 \mu \mathrm{l}$ of $0.5 \%$ agarose in complete RPMI medium. In order to prevent spontaneous aggregation of detached cells, the single-cell suspension was dispersed in $0.33 \%$ agarose in culture medium which is the optimum condition to prevent cell aggregation and permit cell growth [27]. The single-cell suspensions of lung cancer cells in 
$0.33 \%$ agarose $(1500$ cells/250 $\mu \mathrm{l})$ with different concentrations of avicequinone $\mathrm{B}$ were prepared and placed on solidified $0.5 \%$ agarose gel. After the upper layer was left to set in the incubator at $37^{\circ} \mathrm{C}$ for $4 \mathrm{~h}, 250 \mu \mathrm{l}$ of culture medium was added on top and every 3 days. The formation of cancer colonies was investigated under a microscope (Olympus IX51 with DP70) after 14 days.

\section{Western blot analysis}

The alteration of anoikis-regulating proteins in lung cancer cells was analyzed by western blot analysis. Single-cell suspensions of $\mathrm{H} 460$ cells at a density of $1.5 \times 10^{5}$ cells $/ \mathrm{ml}$ were incubated with avicequinone $B(0-4 \mu \mathrm{M})$ for $12 \mathrm{~h}$. Then, the cells were harvested and lysed with lysis buffer containing $20 \mathrm{mM}$ Tris- $\mathrm{HCl}$ (pH 7.5), 1\% Triton X-100, $150 \mathrm{mM}$ sodium chloride, $10 \%$ glycerol, $1 \mathrm{mM}$ sodium orthovanadate, $50 \mathrm{mM}$ sodium fluoride, $100 \mathrm{mM}$ phenylmethylsulfonyl fluoride, and a commercial protease inhibitor mixture (Roche Applied Science) at $4{ }^{\circ} \mathrm{C}$ for $60 \mathrm{~min}$. Cell lysates were collected and determined for total protein content by using the BCA protein assay kit (Pierce, Rockford, IL, USA). An equal amount of protein from each sample was resolved under denaturing conditions by $10 \%$ SDS-PAGE and transferred onto a nitrocellulose membrane. The membranes are blocked for $1 \mathrm{~h}$ in $5 \%$ non-fat dry milk in TBST (25 mM Tris-HCl, pH 7.4, $125 \mathrm{mM}$ sodium chloride, $0.05 \%$ Tween 20 ) before the incubation with specific primary antibody at $4{ }^{\circ} \mathrm{C}$ for $12 \mathrm{~h}$. After washing three times $(5 \mathrm{~min})$ with TBST, the membranes were probed with HRP-conjugated secondary antibody for $2 \mathrm{~h}$ at room temperature. The signal of immunoreactive proteins was detected by enhanced chemiluminescence (Supersignal West Pico; Thermo Fisher Scientific, Waltham, MA, USA). The quantitative analysis was performed with the analyst/ PC densitometry software (Bio-Rad Laboratories, Hercules, CA, USA).
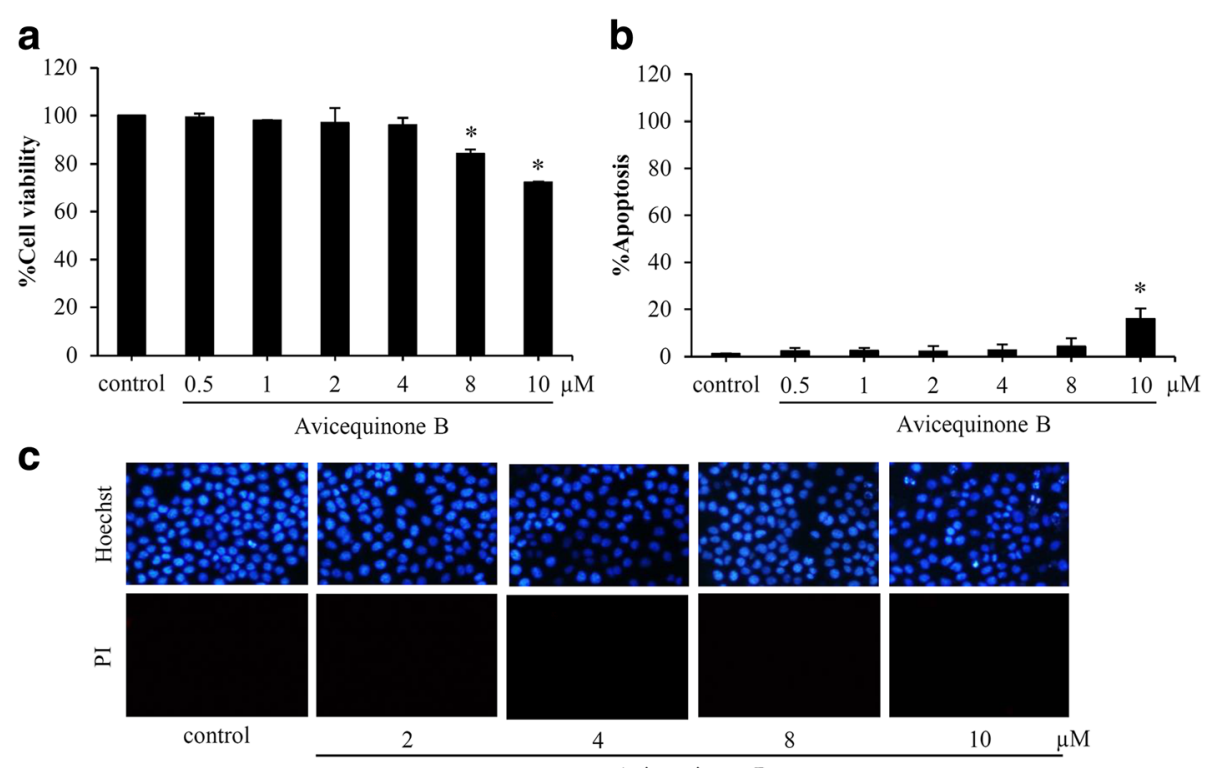

Avicequinone B

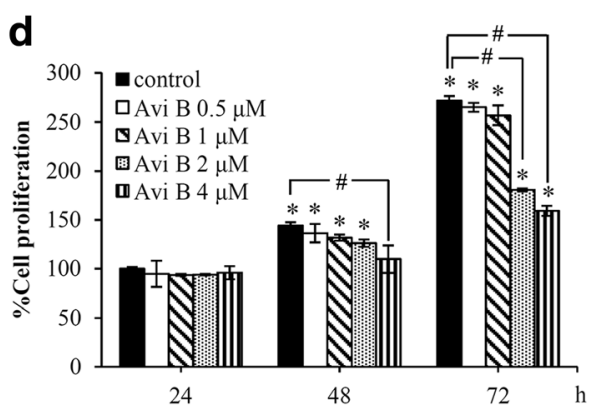

Fig. 2 Cytotoxicity of avicequinone B in human lung cancer cells. a MTT assay revealed the significant reduction of cell viability in lung cancer H460 cells after treatment with 8-10 $\mu \mathrm{M}$ of avicequinone B for $24 \mathrm{~h}$. b Avicequinone B at $10 \mu \mathrm{M}$ induced apoptosis cell death in human lung cancer cells. c Costaining with Hoechst33342/PI demonstrated that no necrosis cell death was detected in $\mathrm{H} 460$ cells at all treatment of avicequinone B. d The suppression on proliferation in adherent lung cancer cells was significantly notified in $\mathrm{H} 460$ cells incubated with $2-4 \mu \mathrm{M}$ of avicequinone B for $72 \mathrm{~h}$. Data represent the means $\pm \mathrm{SD}(n=3) .{ }^{*}, *$ $p \leq 0.05$ versus untreated control cells 


\section{Statistical analysis}

Mean data from three independent experiments were normalized to result of non-treated control. Statistical analysis was performed using one-way ANOVA following with post-hoc test. $p<0.05$ was considered as statistically significant.

\section{Results}

Cytotoxicity of avicequinone B in human lung cancer cells To investigate the effect of avicequinone $B$ on anoikis, the cytotoxicity of the compound in lung cancer H460 cells was firstly elucidated. Cell viability was examined by MTT assay after treatment of the cells with avicequinone $B$ at 0-10 $\mu \mathrm{M}$ for $24 \mathrm{~h}$. Cytotoxic profile of avicequinone $\mathrm{B}$ was shown in fig. 2. In detail, the significant reduction of \%cell viability was observed in the cells treated with 8-
$10 \mu \mathrm{M}$ of avicequinone B (Fig. 2a). Figure 2b indicates the increase of apoptosis cell death in H460 cells after treatment with $10 \mu \mathrm{M}$ of avicequinone B. There was no observation of necrosis cells stained with red fluorescence of PI in all treatment of avicequinone B (Fig. 2c). These results demonstrated that non-toxic concentrations of avicequinone B in human lung cancer $\mathrm{H} 460$ cells were between 0 . 5 to $4 \mu \mathrm{M}$.

The inhibitory effect of avicequinone B on proliferation in human lung cancer cells was further evaluated. Figure $2 \mathrm{~d}$ indicates that treatment with $2-4 \mu \mathrm{M}$ of avicequinone B for $72 \mathrm{~h}$ significantly suppressed \%cell proliferation in lung cancer H460 cells compared with nontreated control cells. Notably, the anti-proliferative activity of avicequinone B $(4 \mu \mathrm{M})$ was early observed after $48 \mathrm{~h}$ of incubation time.
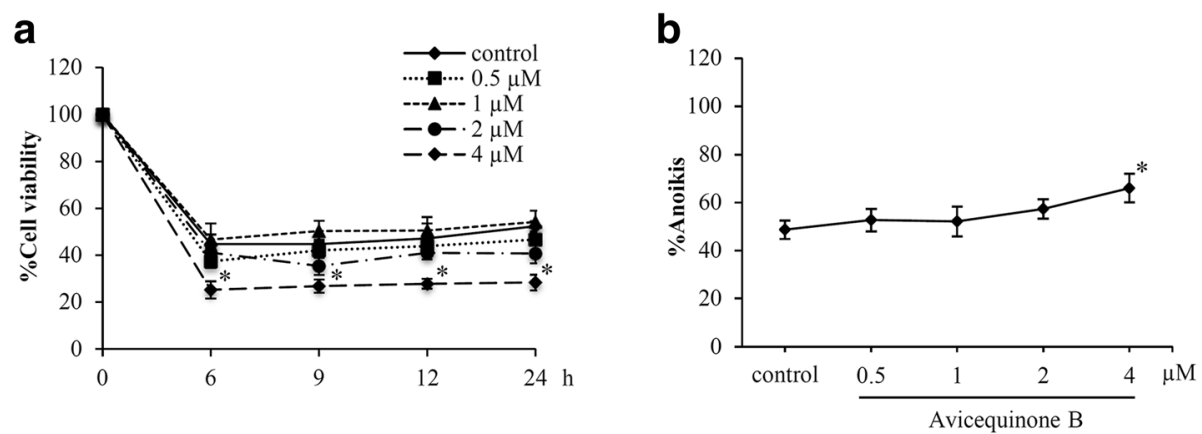

C
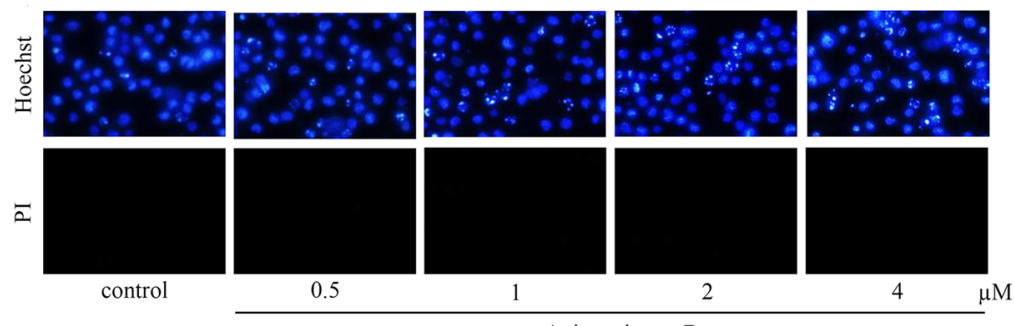

Avicequinone B

d

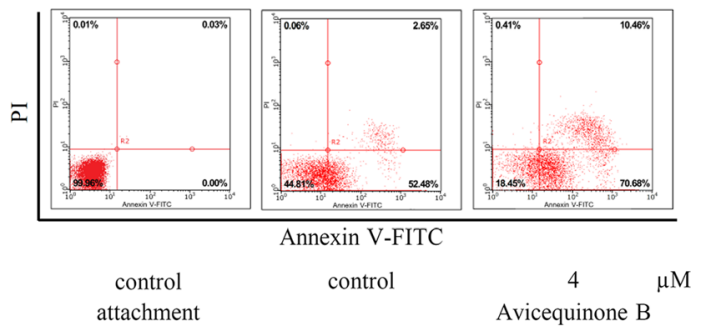

e

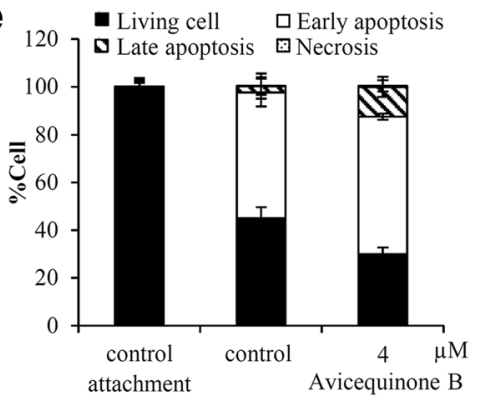

Fig. 3 Avicequinone B sensitized anoikis in human lung cancer cells. a The reduction of viability was early observed in lung cancer $\mathrm{H} 460$ cells after culture under detachment condition for $6 \mathrm{~h}$. b Avicequinone B at $4 \mu \mathrm{M}$ significantly induced anoikis in $\mathrm{H} 460$ cells that were culture under detachment condition for 24 h. c Bright blue fluorescence of Hoechst33342 indicated DNA condense and apoptosis body was indicated in $\mathrm{H} 460$ cells treated with $4 \mu \mathrm{M}$ of avicequinone B. $\mathbf{d}$ Detachment-induced apoptosis was evidenced with histograms obtained from flow cytometry analysis of $\mathrm{H} 460$ cells at anchorage culture (control attachment), detachment without treatment for $24 \mathrm{~h}$ (control) and detachment with $4 \mu \mathrm{M}$ of avicequinone B for $24 \mathrm{~h}$. e The detection early and late apoptosis without necrosis cells was remarkably increased after incubation of non-adherent H460 cells with avicequinone B at $4 \mu \mathrm{M}$. ${ }^{*} p \leq 0.05$ versus untreated control cells at the same time point 


\section{Anoikis sensitizing effect of avicequinone B in H460 lung cancer cells}

Detachment-induced cell death was assessed in human lung cancer cells through the culture of H460 cells as single-cell suspension in non-adhesive poly-HEMA coated-plates. After 0-24 h of incubation with non-toxic concentrations $(0-4 \mu \mathrm{M})$ of avicequinone $\mathrm{B}$, the survival of the cells was determined by XTT assay. The reduction of cell survival was detected in the control cells as early as $6 \mathrm{~h}$ after detachment (Fig. 3a). For treated cells, avicequinone $\mathrm{B}$ at $4 \mu \mathrm{M}$ significantly diminished viability of H460 cells compared with non-treated control cells at the same time point. Co-staining with Hoechst33342 and PI confirmed the anoikis sensitizing effect of avicequinone B. Induction of apoptosis without presenting of necrosis was illustrated in avicequinone B-treated H460 cells (Fig. 3c). Figure 3b shows the significant augmentation of anoikis in $\mathrm{H} 460$ cells after incubation with $4 \mu \mathrm{M}$ of avicequinone B for $24 \mathrm{~h}$.

Flow cytometry analysis also indicated the presence of anoikis in human lung cancer cells. Annexin V-FITC which interacts with phosphatidylserine on the cell membrane of apoptosis cells [28] was dramatically detected in H460 cells cultured in ultra-low attachment plate for $24 \mathrm{~h}$ (Fig. 3d). The higher number of early (Annexin V-FITC positive) and late (Annexin V-FITC positive and PI positive) apoptosis were obviously notified in detached $\mathrm{H} 460$ cells incubated with $4 \mu \mathrm{M}$ of avicequinone $\mathrm{B}$ compared with the non-adherent control cells (Fig. 3e). These results evidenced the anoikis sensitizing activity of avicequinone B in human lung cancer cells.

\section{Avicequinone B suppresses cancer cell growth in anchorage-independent condition}

The effect of avicequinone B on capability to growth and survive under detachment condition was further evaluated in soft-agar assay. Human lung cancer H460 cells were anchorage-independently grown in $0.33 \%$ agarose gel supplemented with culture medium in presence or absence of avicequinone B $(0.5-4 \mu \mathrm{M})$. Figure $4 \mathrm{a}$ presents the colony formation initiating from a single cell of H460 after 14 days of culture under detachment condition. The reduction of both relative colony number and size was significantly observed in H460 cells treated with 2-4 $\mu \mathrm{M}$ of avicequinone B (Fig. $4 \mathrm{~b}$ and $\mathrm{c}$ ). Intriguingly, avicequinone $\mathrm{B}$ at $4 \mu \mathrm{M}$ obviously suppressed proliferation in lung cancer cells at both anchoragedependent (Fig. 2d) and -independent condition.

\section{Avicequinone B decreases anti-apoptotic proteins in non-anchorage lung cancer cells}

Anoikis is apoptosis cell death induced by detachment condition, the alteration of apoptosis-regulating proteins including Bcl-2, Mcl-1, Bax and caveloin-1 was examined in $\mathrm{H} 460$ cells treated with avicequinone B. In order to escape from anoikis, human lung cancer H460 cells can sustain the level of anti-apoptosis proteins during non-adherent circumstance [29]. Avicequinone $\mathrm{B}$ at $4 \mu \mathrm{M}$ significantly reduced the level of caveolin-1 in lung cancer cells detached for $12 \mathrm{~h}$ (Fig. $5 a)$. Moreover, treatment with $2-4 \mu \mathrm{M}$ of avicequinone B significantly declined anti-apoptotic Bcl-2 family proteins, Bcl-2 and $\mathrm{Mcl}-1$ (Fig. 5b). It is worth noting that the expression of Bax, a pro-apoptosis
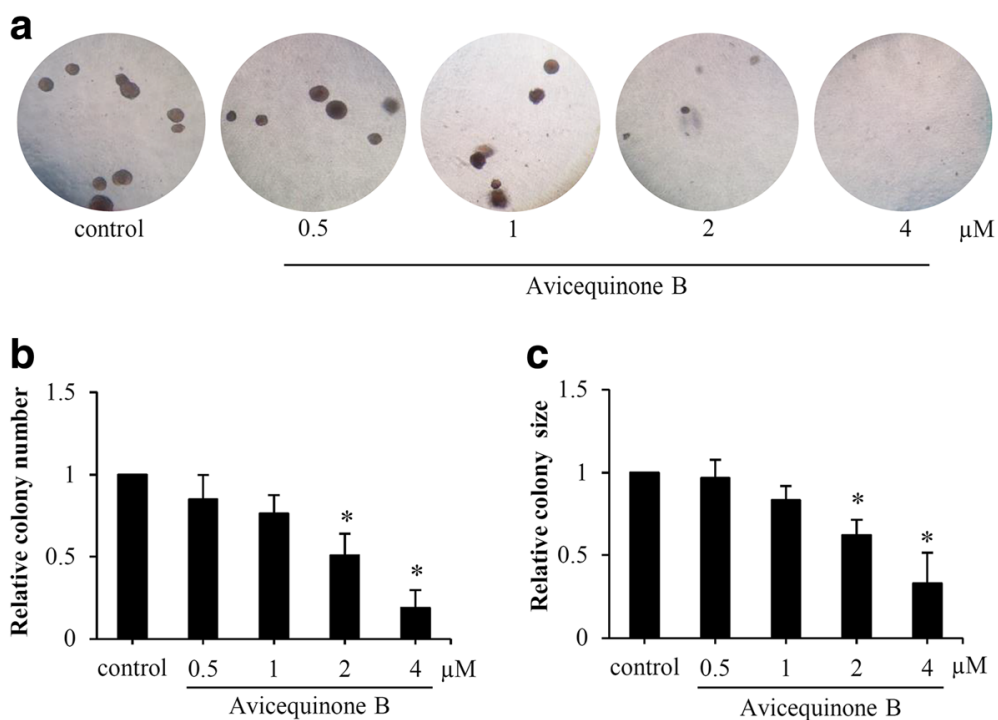

Fig. 4 Effect of avicequinone B on anchorage-independent growth. a Colony formation of single-cell H460 cells was evaluated under a microscope after culture in soft agar for 14 days. $\mathbf{b}$ Relative colony number and $\mathbf{c}$ relative colony size were gradually decreased incubation of single-cell $\mathrm{H} 460$ with 1-4 $\mu \mathrm{M}$ of avicequinone B. Data represent the means $\pm \mathrm{SD}(n=3) .{ }^{*} p \leq 0.05$ versus untreated control cells 
a

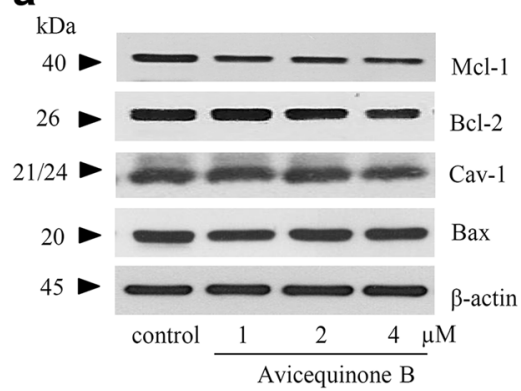

C

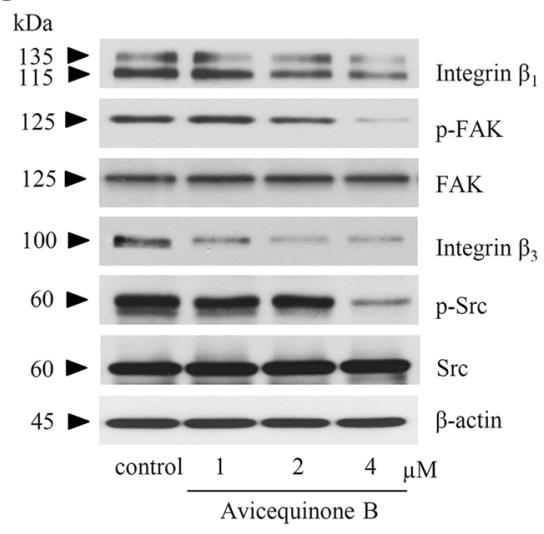

e

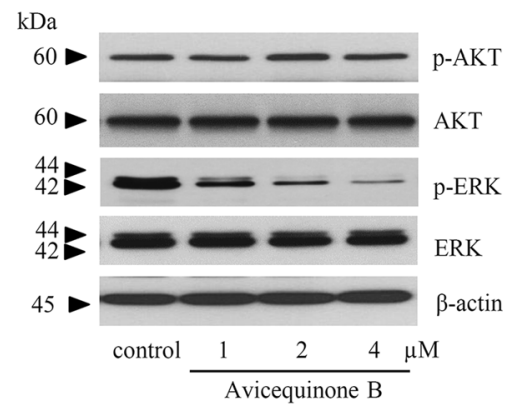

b

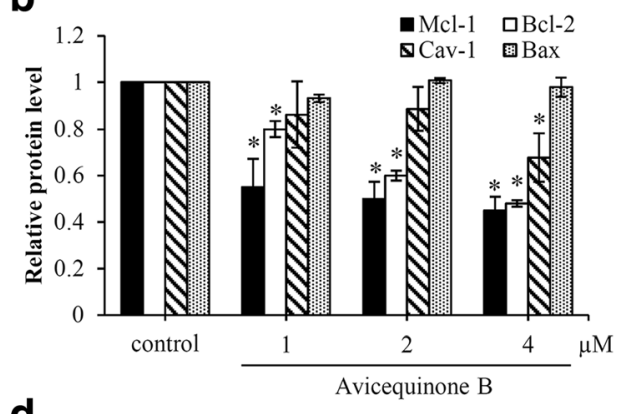

d

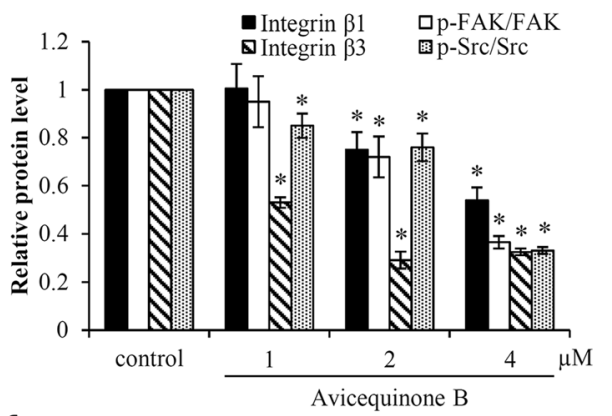

f

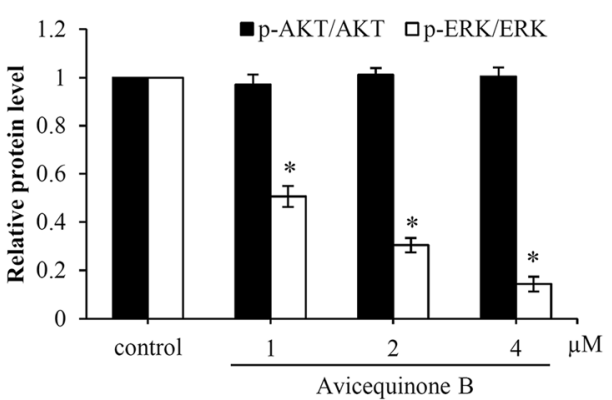

Fig. 5 Avicequinone B down-regulated anti-apoptosis proteins and pro-survival signaling. a Western blot analysis revealed the reduction of anti-apoptosis proteins, Mcl-1 and Bcl-2 in H460 cells treated with avicequinone B (1-4 $\mu \mathrm{M})$ under detachment condition for $12 \mathrm{~h}$. $\mathbf{b}$ The decrease of caveolin-1 (Cav-1) was significantly notified in non-adherent $\mathrm{H} 460$ cells incubated with avicequinone $B$ at $4 \mu \mathrm{M}$. c Low expression level of integrin $\beta 1$ and $\beta 3$ were demonstrated in avicequinone B-treated lung cancer cells. $\mathbf{d}$ Downstream pro-survival signaling of integrin including p-FAK (Y 397) associating with p-Src

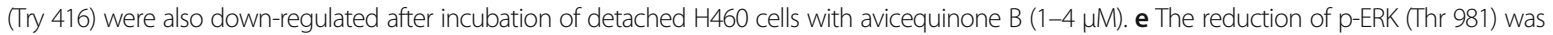
significantly notified while $\mathbf{f}$ there was no alteration of p-AKT (Ser 473)/AKT in avicequinone-treated lung cancer cells. Data represent the means \pm SD $(n=$ 3). ${ }^{*} p \leq 0.05$ versus untreated control cells

protein was not altered in response to the treatment of avicequinone B $(1-4 \mu \mathrm{M})$ for $12 \mathrm{~h}$ (Fig. $5 \mathrm{a}$ and $\mathrm{b}$ ).

\section{Down-regulation of integrin mediated-survival signal by avicequinone $B$}

In order to proliferate under non-adherent condition, anoikis resistant cancer cells substantially activate prosurvival pathways [9]. Thus, the alteration on integrin mediated-survival signal was investigated in H460 cells cultured with avicequinone B. Western blot analysis obviously revealed the down-regulation of integrin $\beta 1$ and $\beta 3$ in human lung cancer cells treated with $4 \mu \mathrm{M}$ of avicequinone $\mathrm{B}$ under detachment condition (Fig. 5c). Interestingly, the reduction of integrin $\beta 3$ was also notified at low concentrations $(1-2 \mu \mathrm{M})$ of avicequinone B. Figure $5 \mathrm{~d}$ indicates the reduction of $\mathrm{p}$-FAK and $\mathrm{p}$-Src, down-stream signaling molecules of integrins in $\mathrm{H} 460$ cells treated with avicequinone $\mathrm{B}$. The alteration on level of AKT and ERK protein, pro-survival molecules activated by $\mathrm{p}$-Src was further investigated [30]. As presented in fig. $5 \mathrm{e}$ and $\mathrm{f}$, the diminution of activated ERK (p-ERK) was notified in detached H460 cells incubated with avicequinone B (1- 
$4 \mu \mathrm{M})$. Meanwhile there were no significant alteration of $\mathrm{AKT}$ and $\mathrm{p}$-AKT expression in avicequinone B treatedH460 cells compared with non-treated control. This inhibitory effect on integrin/FAK/Src survival pathway corresponded with sensitization to anoikis (Fig. 3) and low colony formation (Fig. 4) in human lung cancer cells exposed with avicequinone $\mathrm{B}$.

\section{Avicequinone B sensitizes anoikis and suppresses anchorage-independent growth in various lung cancer cells}

In order to confirm anoikis sensitizing effect of avicequinone $\mathrm{B}$, the detachment-induced cell death was performed in human lung cancer H292 and H23 cells. Figure 6a and $\mathrm{b}$ indicate that avicequinone $\mathrm{B}$ at non-toxic concentrations (2-4 $\mu \mathrm{M}$; data not shown) significantly reduced viability in non-adherent H292 and H23 cells, respectively. Inspiringly, the sensitizing activity of avicequinon $\mathrm{B}$ on detachment-induced cell death was distinctly observed at lower dose $(2 \mu \mathrm{M})$ in both $\mathrm{H} 292$ and H23 lung cancer cells compared with $\mathrm{H} 460$ cells which only responded to
$4 \mu \mathrm{M}$ of avicequinon B (Fig. 3a). Soft agar assay demonstrated the diminution of both colony number and size in H292 (Fig. 6c) and H23 (Fig. 6d) treated with 2-4 $\mu \mathrm{M}$ of avicequinone $B$. These data strengthened the antimetastasis activity of avicequinone B on induction of anoikis and inhibition on survival under detachment condition in human lung cancer cells.

\section{Discussion}

The capability to growth and escape from cell death under detachment condition has been found in non-adherent tumor cells circulating in blood and lymphatic system [31]. In order to resist to detachment-induced cell death, cancer cells acquire the high expression of anti-apoptosis proteins and anoikis resistant mechanisms [6, 31, 32]. Previously, caveolin-1 was shown to inhibit anoikis through the preservation of anti-apoptosis Mcl-1 protein in detached lung cancer cells [25]. Caveolin-1 was shown to be declined in response to the detachment of cells from ECM and the sustained level of the protein confers anoikis resistance [33]. Furthermore, the augmentation of $\mathrm{Bcl}-2$ and diminution of
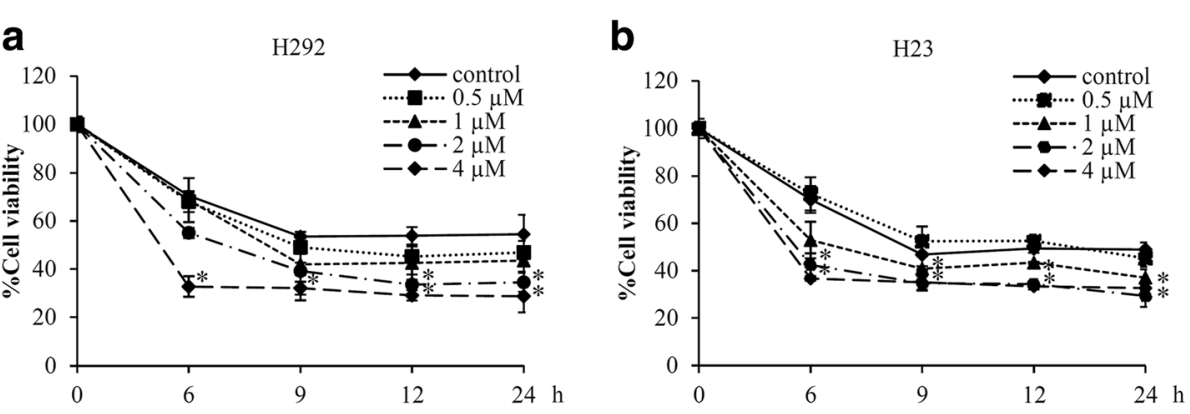

C
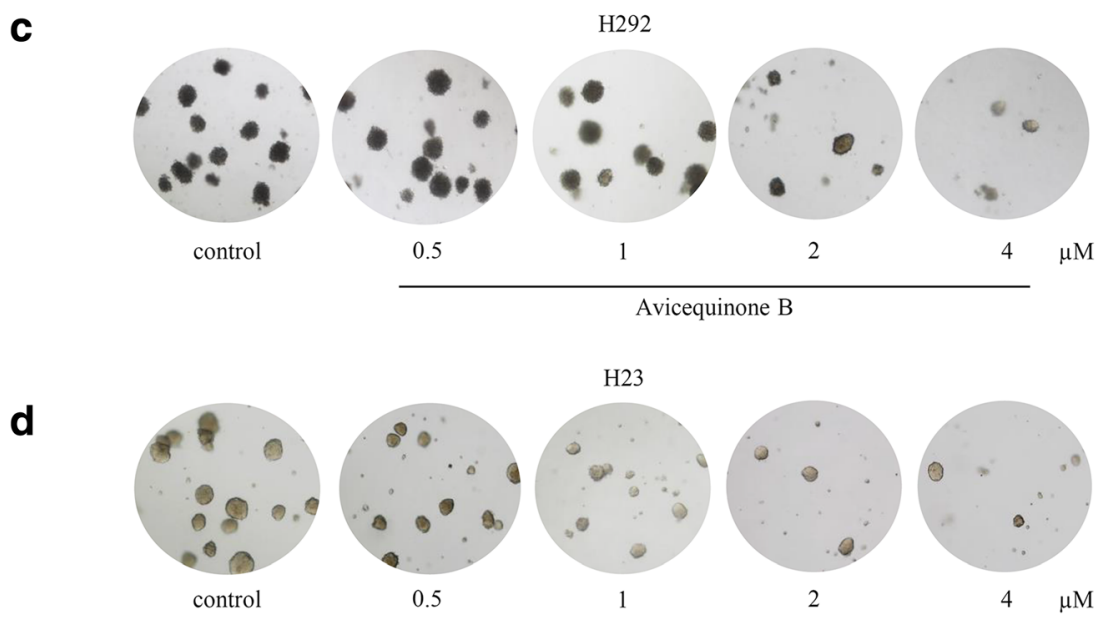

Avicequinone B

Fig. 6 Avicequinone B restrained survival under detachment condition in various lung cancer cells. The lower viability of non-adherent $\mathbf{a} \mathrm{H} 292$ and $\mathbf{b} \mathrm{H} 23$ lung cancer cells was significantly notified in the cells incubated with avicequinone B at 2-4 $\mu \mathrm{M}$ compared with non-treated control. Anchorage-independent growth assay revealed the reduction of both number and size of forming colonies in lung cancer $\mathbf{c} \mathrm{H} 292$ and $\mathbf{d} \mathrm{H} 23$ cells after culture with 2-4 $\mu \mathrm{M}$ of avicequinone B for 14 days. Data represent the means \pm SD $(n=3)$. ${ }^{*} p \leq 0.05$ versus untreated control cells at the same time point 
Bax also manipulate anoikis in cancer cells [34]. In this study, anoikis sensitizing effect of avicequinone B in human lung cancer cells involved with the down-regulation of caveolin-1 together with the reduction of Mcl-1 and $\mathrm{Bcl}-2$ (Fig. 5). Although the decrease of Mcl-1 and Bcl-2 was notified after treatment with avicequinone $B$ at $1-4 \mu \mathrm{M}$, the significantly reduction of caveolin-1 and induction of anoikis were only observed in human lung cancer cells incubated with avicequinone $\mathrm{B}$ at $4 \mu \mathrm{M}$. These results support the critical role of caveolin- 1 on modulation of anoikis resistance in human lung cancer cells $[16,17]$.

Integrins are transmembrane molecules that regulate not only cell adhesion but also various cellular signaling pathways [8]. The interaction between integrins and protein components in ECM or specific ligands activate downstream FAK at focal adhesion complex consequence with phosphorylation of pro-survival proteins. In spite of loss of anchorage with ECM, highly metastatic cancer cells are able to generate integrin survival signals resulting in resistance to anoikis $[10,12,35]$. The up-regulation of integrin $\beta 1$ and $\beta 3$ influences with various aggressive behaviors in cancer cells $[36,37]$. Recent study revealed that the diminution of $\beta 1$ and $\beta 3$ integrins suppresses survival and growth under detachment condition in human lung cancer cells [38]. Herein, suppression on integrin survival pathway in lung cancer cells induced by avicequinone $\mathrm{B}$ was elucidated. There was the reduction of integrin $\beta 1$ and $\beta 3$ level consequence with the restrain of downstream signaling molecules, p-FAK and $\mathrm{p}$-Src in non-adherent lung cancer cells treated with avicequinone $\mathrm{B}$.

The up-regulation of anti-apoptotic proteins and pro-survival signal has been revealed in lung cancer cells with anoikis resistant phenotype [39]. Downregulation of caveolin-1, Mcl-1 and Bcl-2 as well as suppression on AKT and ERK activation successfully initiate detachment-induced cell death in anoikisresistant lung cancer cells [40, 41]. The suppression on integrin/FAK/Src pathway consequence with the reduction of pERK/ERK and diminution of antiapoptosis Bcl-2 family proteins evidence the sensitizing effect of avicequinone $\mathrm{B}$ in anoikis resistant lung cancer cells.

Phosphorylation on FAK and Src leading to formation FAK-Src complex which modulates metastasis features such as migration and anchorage-independent growth [42]. Therefore, the suppression on integrin/FAK/Src signaling has been recognized as targeted pathway for treatment metastasis cancer [43]. Inhibition on migration and invasion of naphthoquinone compound has been demonstrated in cancer cells [22]. Taken together with the anoikis sensitizing activity of avicequinone $\mathrm{B}$ obtained from this study, these data strengthened the possibility to develop naphthoquinones and their derivatives as novel anti-metastasis drugs.

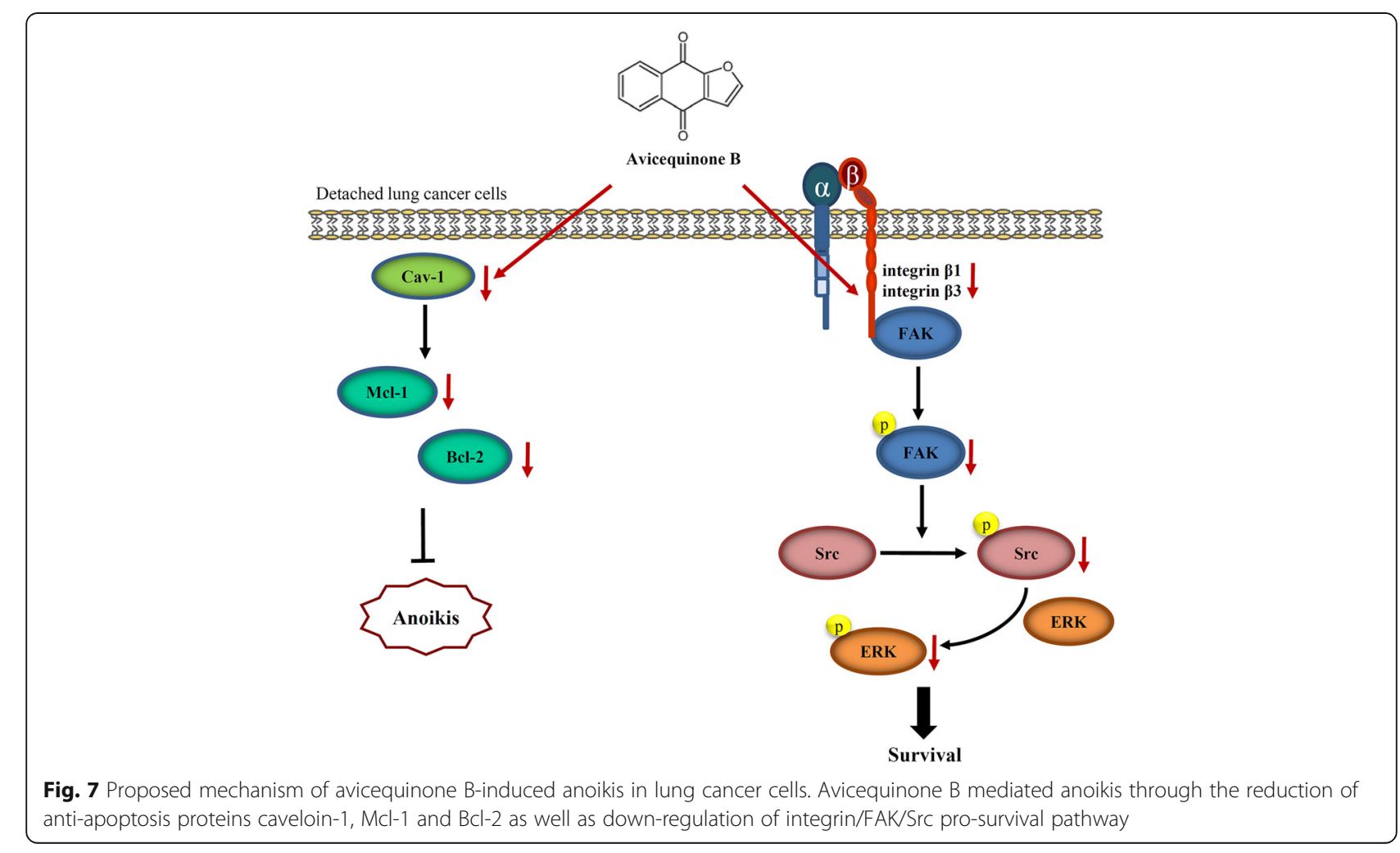




\section{Conclusions}

In conclusion, our study provided the evidence indicating that avicequinone B suppressed survival and induced anoikis in human lung cancer cells under detachment condition through inhibition on integrin/FAK/Src signaling and down-regulation of anti-apoptosis protein including cavelolin-1, Mcl-1 and Bcl-2 (Fig. 7). These data support the further development of avicequinone $B$ as an effective treatment to overcoming cancer metastasis.

\section{Abbreviations \\ AKT: Phospho kinase B; Bax: BCl-2-associated X protein; BCA: Bicinchoninic acid; BCl-2: B-cell lymphoma 2; Cav-1: Caveolin-1; DBU: 1,8- diazabicyclo[5.4.0] undec-7-ene; DMSO: Dimethysulfoxide; ECM: Extracellular matrix; ERK: Extracellular signal-regulated kinase; FAK: Focal adhesion kinase; FBS: Fetal bovine serum; HRP: Horseradish peroxidase; Mcl-1: Myeloid cell leukemia 1; MTT: 3-(4,5-Dimethylthiazol-2-yl)-2,5-diphenyltetrazolium bromide; OD: Optical density; p-AKT: Phosphorylated phospho kinase B; PBS: Phosphate buffer saline; p-ERK: Phosphorylated extracellular signal- regulated kinase; p-FAK: Phosphorylated focal adhesion kinase; PI: Propidium iodide; PI3K: Phosphatidylinositol-4,5-bisphosphate 3-kinase; $p$ - Src: Phosphorylated proto-oncogene tyrosine-protein kinase; RPMI: Roswell Park Memorial Institute; SDS-PAGE: Sodium dodecyl sulfate polyacrylamide gel electrophoresis; Src: Proto-oncogene tyrosine-protein kinase; THF: Tetrahydrofuran; XTT: 2,3-b-(2-methoxy-4-nitro-5-sulfophenyl)-2H- tetrazolium-5-carboxanilide salt}

\section{Funding}

The work was supported by the Thailand Research Fund under Grant [MRG5980143] and a research grant from the 90th Anniversary of Chulalongkorn University Ratchadaphiseksomphot Endowment Fund.

\section{Availability of data and materials}

All data generated or analyzed during this study are included in this article.

\section{Authors' contributions}

Conceived and designed the experiments: PC and CC. Synthesized the compound: WK, WD and SC. Performed the experiments: AP, SS PC and CC. Analysis and interpretation of data: PC and CC. Wrote the paper: SC, PC and CC. All authors read and approved the final manuscript.

\section{Ethics approval and consent to participate}

Not applicable.

\section{Consent for publication}

All the authors have read and approved the paper for publication.

\section{Competing interests}

The authors declare that they have no competing interests.

\section{Publisher's Note}

Springer Nature remains neutral with regard to jurisdictional claims in published maps and institutional affiliations.

\section{Author details}

${ }^{1}$ Department of Biochemistry and Microbiology, Faculty of Pharmaceutical Sciences, Chulalongkorn University, Bangkok 10330, Thailand. ${ }^{2}$ Department of Pharmacognosy and Pharmaceutical Botany, Faculty of Pharmaceutical Sciences, Chulalongkorn University, 10330 Bangkok, Thailand. ${ }^{3}$ Department of Pharmacology and Physiology, Faculty of Pharmaceutical Sciences, Chulalongkorn University, Bangkok 10330, Thailand. ${ }^{4}$ Cell-based Drug and Health Products Development Research Unit, Faculty of Pharmaceutical Sciences, Chulalongkorn University, Bangkok 10330, Thailand.
Received: 23 November 2017 Accepted: 3 April 2018

Published online: 09 April 2018

\section{References}

1. Vansteenkiste J, De Ruysscher D, Eberhardt WE, Lim E, Senan S, Felip E, et al. Early and locally advanced non-small-cell lung cancer (NSCLC): ESMO Clinical Practice Guidelines for diagnosis, treatment and follow-up. Ann Oncol. 2013;28:vi89-98.

2. Riihimäki $M$, Hemminki A, Sundquist $K$, Hemminki K. Causes of death in patients with extranodal cancer of unknown primary: searching for the primary site. BMC Cancer. 2014;14:439.

3. Nichols L, Saunders R, Knollmann FD. Causes of death of patients with lung cancer. Arch Pathol Lab Med. 2012;136:1552-7.

4. Popper HH. Progression and metastasis of lung cancer. Cancer Metastasis Rev. 2016;35:75-91.

5. D'Antonio C, Passaro A, Gori B, Del Signore E, Migliorino MR, Ricciardi S, Fulvi $A$, de Marinis F. Bone and brain metastasis in lung cancer: recent advances in therapeutic strategies. Ther Adv Med Oncol. 2014;6:101-14.

6. Simpson $\mathrm{CD}$, Anyiwe K, Schimmer AD. Anoikis resistance and tumor metastasis. Cancer Lett. 2008;272:177-85.

7. Frisch SM, Ruoslahti E. Integrins and anoikis. Curr Opin Cell Biol. 1997;9:701-6.

8. Vachon PH. Integrin signaling, cell survival, and anoikis: distinctions, differences, and differentiation. J Signal Transduct. 2011;2011:738137.

9. Paoli P, Giannoni E, Chiarugi P. Anoikis molecular pathways and its role in cancer progression. Biochim Biophys Acta. 1833;2013:3481-98.

10. Felding-Habermann B, Fransvea E, O'Toole TE, Manzuk L, Faha B, Hensler M. Involvement of tumor cell integrin alpha $v$ beta 3 in hematogenous metastasis of human melanoma cells. Clin Exp Metastasis. 2002;19:427-36.

11. Díaz-Montero CM, Wygant JN, Mclntyre BW. PI3-K/Akt-mediated anoikis resistance of human osteosarcoma cells requires Src activation. Eur J Cancer. 2006;42:1491-500

12. Haenssen KK, Caldwell SA, Shahriari KS, Jackson SR, Whelan KA, Klein-Szanto AJ, Reginato MJ. ErbB2 requires integrin alpha5 for anoikis resistance via Src regulation of receptor activity in human mammary epithelial cells. J Cell Sci. 2010;123:1373-82

13. Lee $Y C$, Jin JK, Cheng CJ, Huang CF, Song JH, Huang M, Brown WS, Zhang S, Yu-Lee LY, Yeh ET, Mclntyre BW, Logothetis CJ, Gallick GE, Lin SH. Targeting constitutively activated $\beta 1$ integrins inhibits prostate cancer metastasis. Mol Cancer Res. 2013;11:405-17.

14. Stucci S, Tucci M, Passarelli A, Silvestris F. Avß3 integrin: Pathogenetic role in osteotropic tumors. Crit Rev Oncol Hematol. 2015;96:183-93.

15. Fiucci G, Ravid D, Reich R, Liscovitch M. Caveolin-1 inhibits anchorageindependent growth, anoikis and invasiveness in MCF-7 human breast cancer cells. Oncogene. 2002;21:2365-75.

16. Rungtabnapa P, Nimmannit U, Halim H, Rojanasakul $Y$, Chanvorachote $P$. Hydrogen peroxide inhibits non-small cell lung cancer cell anoikis through the inhibition of caveolin-1 degradation. Am J Physiol Cell Physiol. 2011;300:235-45.

17. Halim H, Luanpitpong S, Chanvorachote P. Acquisition of anoikis resistance up-regulates caveolin-1 expression in human non-small cell lung cancer cells. Anticancer Res. 2012;32:1649-58.

18. Ravid D, Maor S, Werner H, Liscovitch M. Caveolin-1 inhibits cell detachment-induced p53 activation and anoikis by upregulation of insulinlike growth factor-I receptors and signaling. Oncogene. 2005;24:1338-47.

19. Boisvert-Adamo K, Longmate W, Abel EV, Aplin AE. Mcl-1 is required for melanoma cell resistance to anoikis. Mol Cancer Res. 2009;7:549-56.

20. Tang W, Feng X, Zhang S, Ren Z, Liu Y, Yang B, Iv B, Cai Y, Xia J, Ge N. Caveolin-1 confers resistance of hepatoma cells to Anoikis by activating IGF1 pathway. Cell Physiol Biochem. 2015;36:1223-36.

21. Ito C, Katsuno S, Kondo Y, Tan HT, Furukawa H. Chemical constituents of Avicennia alba. Isolation and structural elucidation of new naphthoquinones and their analogues. Chem Pharm Bull. 2000;48:339-43.

22. Lin KL, Su JC, Chien CM, Tseng CH, Chen YL, Chang LS, Lin SR. Naphtho[1,2-b]furan-4,5-dione induces apoptosis and S-phase arrest of MDA-MB-231 cells through JNK and ERK signaling activation. Toxicol in Vitro. 2010;24:61-70.

23. Tsai PC, Chu CL, Fu YS, Tseng CH, Chen YL, Chang LS, Lin SR. Naphtho[1,2b]furan-4,5-dione inhibits MDA-MB-231 cell migration and invasion by suppressing Src-mediated signaling pathways. Mol Cell Biochem. 2014;387: 101-11. 
24. Tseng CH, Chen YL, Yang SH, Peng SI, Cheng CM, Han CH, Lin SR, Tzeng CC. Synthesis and antiproliferative evaluation of certain iminonaphtho[2,3b]furan derivatives. Bioorg Med Chem. 2010;18:5172-82.

25. Chunhacha P, Pongrakhananon V, Rojanasakul Y, Chanvorachote P. Caveolin-1 regulates Mcl-1 stability and anoikis in lung carcinoma cells. Am J Physiol Cell Physiol. 2012;302:C1284-92.

26. Ke X, Li L, Dong HL, Chen ZN. Acquisition of anoikis resistance through CD147 upregulation: a new mechanism underlying metastasis of hepatocellular carcinoma cells. Oncol Lett. 2012;3:1249-54.

27. Borowicz S, Van Scoyk M, Avasarala S, et al. The Soft Agar Colony Formation Assay. J Vis Expe. 2014;2014:51998.

28. van Engeland M, Nieland L, Ramaekers FC, Schutte B, Reutelingsperger CP. Annexin $\mathrm{V}$-affinity assay: a review on an apoptosis detection system based on phosphatidylserine exposure. Cytometry. 1998;31:1-9.

29. Pongrakhananon V, Nimmannit U, Luanpitpong S, Rojanasakul Y, Chanvorachote P. Curcumin sensitizes non-small cell lung cancer cell anoikis through reactive oxygen species-mediated $\mathrm{BCl}-2$ downregulation. Apoptosis. 2010;15:574-85.

30. Kim LC, Song L, Haura EB. Src kinases as therapeutic targets for cancer. Nat Rev Clin Oncol. 2009;6:587-95.

31. Kim YN, Koo KH, Sung JY, Yun UJ, Kim H. Anoikis resistance: an essential prerequisite for tumor metastasis. Int J Cell Biol. 2012;2012:306879.

32. Geiger TR, Peeper DS. The neurotrophic receptor TrkB in anoikis resistance and metastasis: a perspective. Cancer Res. 2005;65:7033-6.

33. Chanvorachote P, Chunhacha P. Caveolin-1 regulates endothelial adhesion of lung cancer cells via reactive oxygen species-dependent mechanism. PLoS One. 2013;8:e57466.

34. Martin SS, Vuori K. Regulation of BCl-2 proteins during anoikis and amorphosis. Biochim Biophys Acta. 1692;2004:145-57.

35. Maiuthed A, Chanvorachote P. Cisplatin at sub-toxic levels mediates integrin switch in lung cancer cells. Anticancer Res. 2014;34:7111-7.

36. Velling T, Nilsson S, Stefansson A, Johansson S. beta1-Integrins induce phosphorylation of Akt on serine 473 independently of focal adhesion kinase and Src family kinases. EMBO Rep. 2004;5:901-5.

37. Bhattacharya S, Ray RM, Johnson LR. Integrin beta3-mediated Src activation regulates apoptosis in IEC-6 cells via Akt and STAT3. Biochem J. 2006;397: 437-47.

38. Puchsaka P, Chaotham C, Chanvorachote P. a-lipoic acid sensitizes lung cancer cells to chemotherapeutic agents and anoikis via integrin $\beta 1 / \beta 3$ downregulation. Int J Oncol. 2016;49:1445-56.

39. Liu G, Meng X, Jin Y, Bai J, Zhao Y, Cui X, Chen F, Fu S. Inhibitory role of focal adhesion kinase on anoikis in the lung cancer cell A549. Cell Biol Int. 2008:32:663-70.

40. Sirimangkalakitti N, Chamni S, Suwanborirux K, Chanvorachote P. Renieramycin M sensitizes Anoikis-resistant H460 lung Cancer cells to Anoikis. Anticancer Res. 2016;36(4):1665-71.

41. Chanvorachote P, Pongrakhananon V, Halim H. Caveolin-1 regulates metastatic behaviors of anoikis resistant lung cancer cells. Mol Cell Biochem. 2015;399:291-302.

42. Westhoff MA, Serrels B, Fincham VJ, Frame MC, Carragher NO. Src-mediated phosphorylation of focal adhesion kinase couples actin and adhesion dynamics to survival signaling. Mol Cell Biol. 2004;24:8113-33.

43. Mitra SK, Schlaepfer DD. Integrin-regulated FAK-Src signaling in normal and cancer cells. Curr Opin Cell Bio. 2006;18:516-23.

\section{Ready to submit your research? Choose BMC and benefit from:}

- fast, convenient online submission

- thorough peer review by experienced researchers in your field

- rapid publication on acceptance

- support for research data, including large and complex data types

- gold Open Access which fosters wider collaboration and increased citations

- maximum visibility for your research: over $100 \mathrm{M}$ website views per year

At BMC, research is always in progress.

Learn more biomedcentral.com/submissions 